\title{
Correction to: Pretreatment tumor sampling and prognostic factors in patients with soft-tissue sarcoma of the head and neck
}

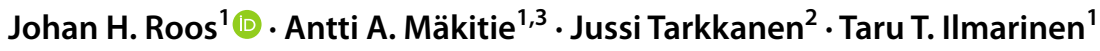

Published online: 4 December 2021

(c) The Author(s) 2021

\section{Correction to: European Archives of Oto-Rhino-Laryngology https://doi.org/10.1007/s00405-021-07162-0}

In the original publication of the article, affiliation 1 was published incorrectly and the correct affiliation 1 should read as below,

Department of Otolaryngology, Head and Neck Surgery, University of Helsinki and HUS Helsinki University Hospital, Helsinki, Finland

In addition, under funding section, the university name should read as "Helsinki University Hospital" instead "Helsinki University Central Hospital".

The original article was updated.

Open Access This article is licensed under a Creative Commons Attribution 4.0 International License, which permits use, sharing, adaptation, distribution and reproduction in any medium or format, as long as you give appropriate credit to the original author(s) and the source, provide a link to the Creative Commons licence, and indicate if changes were made. The images or other third party material in this article are included in the article's Creative Commons licence, unless indicated otherwise in a credit line to the material. If material is not included in the article's Creative Commons licence and your intended use is not permitted by statutory regulation or exceeds the permitted use, you will need to obtain permission directly from the copyright holder. To view a copy of this licence, visit http://creativecommons.org/licenses/by/4.0/.

The original article can be found online at https://doi.org/10.1007/ s00405-021-07162-0.

Johan H. Roos

johan.roos@helsinki.fi

1 Department of Otolaryngology, Head and Neck Surgery, University of Helsinki and HUS Helsinki University Hospital, Helsinki, Finland

2 Department of Pathology, HUSLAB, University of Helsinki and Helsinki University Hospital, Helsinki, Finland

3 Research Program in Systems Oncology, Faculty of Medicine, University of Helsinki, Helsinki, Finland
Publisher's Note Springer Nature remains neutral with regard to jurisdictional claims in published maps and institutional affiliations. 